\title{
Stelpurnar í eldhúsinu: viðhorf og aðgerðir á sviði umhverfismála hjá norrænum vátryggingafélögum
}

\author{
Lára Jóhannsdóttir, Snjólfur Ólafsson, Brynhildur Davíosdóttir
}

Ágrip: Í greininni er fjallað um viðhorf til umhverfismála sem fram koma í rannsókn á áhuga og framlagi norrænna skaðatryggingafélaga á úrlausn umhverfislegra vandamála. Fyrirtæki taka á umhverfismálum vegna utanaðkomandi prýstings, eða vegna innri hvata, til að mynda væntinga um að aðgerðir leiði til betri ímyndar, aukinnar sölu eða minni kostnaðar, eða af siðferðilegum hvötum sem byggja á gildismati leiðtoga í viðkomandi fyrirtæki. Rannsóknin leiðir í ljós mun á viðhorfi til umhverfismála innan vátryggingafélaga í svokölluðum eyjahópi annars vegar og meginlandshópi hins vegar. Mun jákvæðari afstaða til umhverfismála má greina hjá síðari hópnum, en jákvæð afstaða til umhverfismála er talin hafa hvetjandi áhrif á aðgerðir á sviði umhverfismála, en neikvæð afstaða sem er sýnileg innan eyjahópsins er talin hafa letjandi áhrif á aðgerðir á pessu sviði.

Abstract: The article discusses the attitudes towards environmental issues that were observed during a study of Nordic non-life insurers' interest in and responses to environmental problems. Companies take environmentally responsible actions because of both external and internal pressures. They may expect that such actions will improve their image, increase sales, or reduce costs; the motivations may also be moral ones that are grounded in values held by company leaders. This study reveals a difference in attitude towards environmental issues between insurers in island settings (Iceland, the Faroe Islands, and the Åland Islands) and insurers in mainland Scandinavia. A greater interest in environmental issues is evident in the mainland group, while the island group places less value on environmental matters. These differences likely lead to varying levels of action on environmental matters.

Citation/Tilvísun: Lára Jóhannsdóttir, Snjólfur Ólafsson, og Brynhildur Davíðsdóttir, „,Stelpurnar í eldhúsinu: Viðhorf og aðgerðir á sviði umhverfismála hjá norrænum vátryggingafélögum,"

Samtíð 1 (2013), 4. http://dx.doi.org/10.12742/samtid.2013.4

Received/Móttekið: 2013-08-31. Accepted/Sambykkt: 2013-10-01. Published/Birt: 2013-12-19.

@ 2013 Authors/Höfundar. This open-access article is published under the terms of the Creative Commons Attribution License, version 3.0 / Greinin er birt íopnum

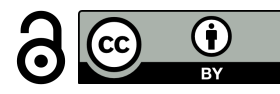
aðgangi undir CC-BY 3.0 leyfi (http://creativecommons.org/licenses/by/3.0) 


\section{Inngangur}

Náttúran er forsendan fyrir tilvist fólks og fyrirtækja vegna peirra auðlinda sem paðan koma. Vaxandi mannfjöldi, aukin framleiðsla og neysla svo og útblástur og úrgangur skapa aukinn prýsting á umhverfið í pví lokaða kerfi sem jörðin er. Umhverfismál eru meðal meginafla (e. megatrends) sem hafa, og munu áfram hafa, mótandi áhrif á löggjöf og rekstrarumhverfi fyrirtækja. Líklegt er að kröfur frá neytendum á sviði umhverfismála muni einnig hafa vaxandi áhrif í komandi framtíð (OECD, 2012; Yoder, Rao \& Bajowala, 2012). Frá pví á sjöunda áratug síðustu aldar hafa fyrirtæki starfað undir síauknum prýstingi um að axla ábyrgð á umhverfismálum og bæta fyrir umhverfislegan skaða sem pau valda með starfsemi sinni. Upp úr 1960 óx svokölluð umhverfishyggja. Kolanámur, framleiðendur hreinsiefna og skordýraeiturs svo og námuvinnsla og grjótnám voru framan af undir mestum prýstingi. Á áttunda áratugnum óx prýstingur á annars konar starfsemi. Par má nefna sem dæmi framleiðendur úðabrúsa og asbests, kjarnorkuvinnslu, málmvinnslu, pungaflutninga, tóbaksframleiðslu og hvalveiðar (Elkington, 1994).

Prýstingurinn kemur utan frá, til dæmis vegna löggjafar og/eða alpjóðlegra umhverfissáttmála, aðgengis að fjármagni frá bönkum eða vátryggingafélögum, markaðslegra krafna frá keppinautum, viðskiptavinum eða iðngreinasamtökum eða krafna frá samfélaginu svo sem frá frjálsum félagasamtökum, aðgerðasinnum, starfsmönnum eða fjárfestum (Hoffman, 2000). Prýstingurinn myndast einnig innan veggja fyrirtækjanna og byggir á peim rekstrarlegu sjónarmiðum að umhverfisábyrgð leiði til fjárhagslegs ávinnings (Porter \& van der Linde, 1995), eða af siðferðilegum hvötum en síðarnefndu sjónarmiðin byggja á gildum sem leiðtogar hafa í heiðri við rekstur fyrirtækjanna (Bansal \& Roth, 2000; Tutore, 2010). Ytri hvatar eru sagðir pvinga fyrirtæki til aðgerða, en innri hvatar stuðla að pví að fyrirtæki taki sjálfviljug frumkvæði á sviði umhverfismála (Bansal \& Roth, 2000; Mygind, 2009; Porter \& van der Linde, 1995; Tutore, 2010).

prátt fyrir að vera flokkuð í hóp lítt mengandi fyrirtækja hafa vátryggingafélög ekki farið varhluta af pessari próun í umhverfismálum. Prýstingur á vátryggingafélög varð fyrst sýnilegur á níunda áratug síðustu aldar (Elkington, 1994). Svokölluð róttæk umhverfishyggja (e. radical greening) er nú á dögum talin meðal helstu áhættupátta í rekstri vátryggingafélaga, en pá er átt við að samfélagslegur prýstingur geti haft neikvæð áhrif á ímynd og orðspor peirra (Ernst \& Young \& Oxford Analytica, 2009, 2010). Meðal umhverfislegra vandamála sem snerta vátryggjendur eru afleiðingar veðurfarstjóna, mengunarmál og ábyrgðartjón sem peim tengjast. Í vandamálum felast jafnframt tækifæri. Hjá vátryggingafélögum felast tækifæri í pví að draga úr áhættu og kostnaði, til dæmis með áhættustjórnun og forvörnum og með pví að draga úr sóun í ferlum og innan aðfangakeðjunnar. Pá er mögulegt að auka tekjur með nýjum og 
endurbættum vörum og pjónustu á sviði umhverfismála og með fjárfestingum í hreinni tækni sem stuðlar að úrlausn umhverfislegra vandamála, til dæmis endurnýjanlegri orku (GEMI, 1998, 2004; Mills, 2007, 2009), svo sem vindorku.

Markmið rannsóknarinnar sem hér er kynnt er að skoða viðhorf stjórnenda og sérfræðinga í norrænum vátryggingafélögum til umhverfisábyrgðar fyrirtækja. Umhverfisábyrgð er ein af meginstoðum samfélagsábyrgðar fyrirtækja (e. corporate social responsibility) eða sjálfbærni fyrirtækja (e. business sustainability), en pessi tvö hugtök eru oft notuð af stjórnendum án skýrrar aðgreiningar (Wilenius, 2005). Pau eru nátengd og byggja á viðleitni fyrirtækja til að bæta pjóðfélagið og stuðla að sjálfbærri próun (e. sustainable development), pað er að segja að pörfum samtímans sé mætt án pess að skerða möguleika komandi kynslóða á að mæta eigin pörfum (World Commission on Environment and Development, 1987). Með pessum hugtökum er leitast við að skilgreina ábyrgð fyrirtækja í víðu samhengi samfélags og umhverfis (Montiel, 2008; Nelson, 2004; Wilenius, 2005). Gengið er út frá peirri tilgátu að gildismat stjórnenda og siðferðileg sjónarmið geti haft áhrif á pað að hvaða marki fyrirtæki axla umhverfislega ábyrgð í eigin rekstri.

Í greininni er leitast við að svara premur rannsóknarspurningum:

- Hvað einkennir viðhorf stjórnenda og sérfræðinga í norrænum vátryggingafélögum til umhverfismála?

- Má útskýra mismunandi viðhorf til umhverfismála í mismunandi tilvikshópum með hluthafa- og haghafakenningum?

— Hvernig endurspeglast viðhorf til umhverfismála í aðgerðum eða aðgerðaleysi vátryggingafélaga?

Greinin er pannig uppbyggð að í kafla 2 er fjallað um umhverfismál og prýsting frá hagsmunaaðilum. Í kafla 3 eru rannsóknaraðferðir skýrðar út. Kafli 4 fjallar um niðurstöður rannsóknarinnar og er fyrst fjallað um viðhorf til umhverfismála sem fram koma í meginlandshópnum en síðan umhverfisleg viðhorf í eyjahópnum. Umræður um niðurstöður eru í kafla 5.

\section{Viðhorf til umhverfismála og prýstingur frá hagsmunaaðilum}

Umhverfisábyrgð er hluti af samfélagslegri ábyrgð fyrirtækja, eins og komið var inn á í innganginum. Í ISO 26000 staðlinum sem gefinn var út árið 2010 er samfélagsleg ábyrgð skilgreind á eftirfarandi máta (International Organization for Standardization, 2011):

Ábyrgð fyrirtækis á peim áhrifum sem ákvarðanir pess og starfsemi hafa á samfélag og umhverfi sem öxluð er með gegnsærri og siðferðilegri háttsemi sem stuðlar að 
1. sjálfbærri próun, par með talið heilsufari og velferð samfélagsins;

2. tekur mið af væntingum hagsmunaaðila;

3. fylgir gildandi lögum og samræmist albjóðlega viðtekinni háttsemi;

4. og hefur verið innleidd innan fyrirtækisins og viðhöfð er í öllum samskiptum pess.

Áherslur í stefnu framkvæmdastjórnar Evrópusambandsins um samfélagslega ábyrgð fyrirtækja eru af svipuðum toga, en par kemur fram að ef fyrirtæki ætli að axla ábyrgð innan samfélagsins purfi pau að búa yfir aðferðum sem gera peim kleift að sampætta félagsleg-, umhverfisleg-, siðferðileg og mannréttindasjónarmið við starfsemina og meginstefnur í nánu samstarfi við hagsmunaaðila fyrirtækisins (European Commission, 2011).

Viðhorf til umhverfismála tengjast viðskiptasiðfræði, en hún snýst um pað hvernig fólk og fyrirtæki haga sér, hvaða meginreglur gilda um starfsemi fyrirtækja, hvaða málefni fengist er við og hvaða vinnuaðferðir eru notaðar. Ákvarðanir purfa að vera siðferðilegs eðlis, en slíkar ákvarðanir hafa verið skilgreindar sem lagalega og siðferðilega ásættanlegar af hálfu samfélagsins, öfugt við ákvarðanir sem teljast ólöglegar og siðferðilega óviðunandi (Jones, 1991). Siðferðilegar ákvarðanir fyrirtækja hafa einnig verið skilgreindar sem ákvarðanir sem hámarka virði fyrirtækja fyrir samfélagið (Guidi, Hillier \& Tarbert, 2008). Bansal og Roth (2000) tilgreina fjóra meginhvata að baki umhverfislegum (eða vistfræðilegum) ákvörðunum fyrirtækja, pað er:1) lagalega hvata, 2) prýsting frá hagsmunaaðilum, 3) fjárhagsleg tækifæri og 4) siðferðileg sjónarmið. Fyrirtæki sem drifin eru áfram af siðferðilegum hvötum gera slíkt vegna pess að um „réttar ákvarðanir“ er að ræða (Wood, 1991). Rannsóknir hafa sýnt að hugmyndafræði, persónuleg gildi og markmið leiðtoga hafa bein eða óbein áhrif á starfshætti fyrirtækja (Cambra-Fierro, Hart, \& Polo-Redondo, 2008), sem og persónuleg gildi starfsmanna og hvort fyrirtækjamenning sé samfélagslega ábyrg eða siðræn (Grojean, Resick, Dickson \& Smith, 2004; Hemingway, 2005). Grojean o.fl. (2004) telja mikilvægt að leiðtogar geri sér grein fyrir pví að persónulegt gildismat peirra og siðferði hefur áhrif á ákvarðanir peirra og aðgerðir. Viðhorf, lífsskoðanir og gildi hafa pví áhrif á pað hvaða stefnu fyrirtæki taka pegar kemur að umhverfismálum (Nidumolu, Prahalad, \& Rangaswami, 2009). Stundum standa persónuleg gildi í vegi fyrir innleiðingu á stefnu fyrirtækja ef um pað er að ræða að persónuleg gildi séu af öðrum toga en áherslur fyrirtækisins.

Mynd 1 sýnir orsakasamhengi að baki einum peirra fjögurra meginhvata sem Bansal og Roth (2000) telja að hafi áhrif á frumkvæði fyrirtækja í umhverfismálum. Myndin sýnir að gildismat leiðtoga tengist siðferðilegum hvötum sem síðan hafa áhrif á frumkvæði fyrirtækja á sviði umhverfismála (Bansal \& Roth, 2000; Tutore, 2010). 
Mynd 1: Tengsl gildismats, siðferðilegra hvata og frumkvøðis í umhverfismálum, aðlagað frá Bansal \& Roth, 2000; Tutore, 2010.

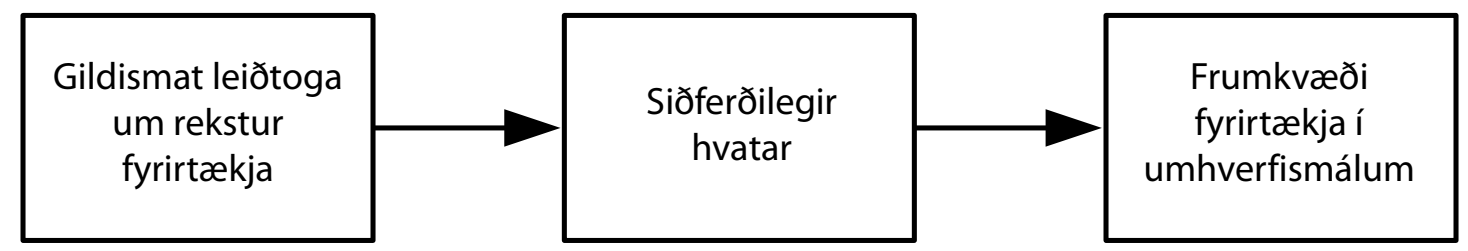

Fyrirtæki starfa ekki í einangrun. Pau purfa á samfélagi og umhverfi að halda og pau hafa áhrif á fólk og umhverfi par sem pau starfa (Smith, 2007). Samkvæmt siðrænum viðskiptum (e. ethical business) er gengið út frá pví að fyrirtækjum vegni vel á sama tíma og pau láti gott af sér leiða (Jones, 2012; Spiller, 2000). En hvað pýðir pað að láta gott af sér leiða? Í sumum tilvikum setja fyrirtæki sér siðareglur (e. ethical business codes) til að starfa eftir en pær fela í sér siðferðileg gildi eða viðmið sem sett eru fram innan fyrirtækja í peim tilgangi að hafa áhrif á hegðun starfsmanna (Thomsen, 2001), svo sem viðmið um réttlæti, sanngirni eða gagnsæi. Viðskipti fyrirtækja lúta pá peim viðmiðum sem skilgreind hafa verið. Í pessu samhengi geta togast á sjónarmið um hag hluthafa (e. shareholder) annars vegar og hag hagsmunaaðila (e. stakeholder) hins vegar. Fyrra sjónarmiðið felur í sér að fyrirtæki beri ekki samfélagslega ábyrgð umfram að auka arð hluthafa í gegnum verðmæta- og atvinnusköpun og pví að fara að lögum og reglum. Síðara sjónarmiðið felur í sér að fyrirtæki axli ábyrgð umfram pað sem lög og reglur kveða á um, til dæmis með pví að bæta úr umhverfis- og samfélagslegum vandamálum til hagsbóta fyrir samfélagið allt. Fimm flokkar einkenna eða pátta sem stuðla að siðrænni fyrirtækjamenningu hafa verið skilgreindir. Peir eru 1) tilgangur fyrirtækja og gildismat, 2) jafnvægi á milli hagsmunaaðila, 3) skilvirk forysta sem sýnir gott fordæmi, 4) heiðarleiki og ráðvendni í ferlum eða starfsháttum og 5) langtímasjónarmið ofar skammtímagróða (Ardichvili, Mitchell \& Jondle, 2009). Par af eru tilgangur og gildismat talin vega pyngst sem undirstaða siðræns rekstrar (Ardichvili, Mitchell \& Jondle, 2009), auk pess sem leiðtogar gegna lykilhlutverki í að stuðla að slíkum rekstri (Schroeder, 2002).

\subsection{Sjónarmið hluthafa og einhliða ávinningur}

Samkvæmt Adam Smith á sjálfsást fólks, par sem eiginhagsmunir stýra aðgerðum, að leiða til jákvæðrar niðurstöðu fyrir heildina (Smith, 1776 / 2005). Af svipuðum toga eru hugmyndir Milton Friedmans (1970), sem fjalla um tengsl á milli samfélagslegrar ábyrgðar og hámörkunar hagnaðar fyrirtækja. Skyldur fyrirtækja gagnvart eigendum og hluthöfum eru augljósar par sem peir trúa stjórnendum fyrir pví að höndla með fjárfestingar með раð аð markmiði að skapa fjárhagslegan ávinning (Smith, 2007). 
Friedman (1970) orðar petta pannig að „samfélagsleg skylda fyrirtækja [sé] ein og aðeins ein, að nýta auðlindir sínar og beina athöfnum sínum í pá veru að auka hagnað sinn, og par af leiðandi hagnað eigenda, svo lengi sem pau fylgja leikreglunum“ sem samfélagið setur peim. Friedman (1970) heldur pví fram að stjórnendur séu ekki að sinna skyldum sínum gagnvart eigendum í peim tilvikum par sem peir velja að draga úr mengun með pví að leggja út í kostnað umfram pað sem kemur sér best fyrir fyrirtækið eða krafist er af peim í lögum, til pess eins að uppfylla samfélagsleg markmið um að bæta umhverfið. Pess háttar eigenda- eða hluthafaprýstingur (e. shareholder pressure) var helsta leiðarljós stjórnenda um langt árabil (Oppenheim o.fl., 2007). Talsmenn pessa sjónarmiðs hafa haldið pví fram að við fullkomnar markaðsaðstæður náist besta niðurstaðan fyrir alla hagsmunaaðila, par með talið umhverfið. petta er pó ekki raunin eins og sjá má á peim umhverfislegu vandamálum sem stafa af rekstri fyrirtækja og samfélagið í heild situr uppi með. Alpjóðaviðskiptastofnunin (the World Trade Organization) fæst við sum pessara vandamála í núverandi Doha-samningaviðræðum, par sem lögð er áhersla á jákvæða útkomu á sviði viðskipta, próunar og umhverfismála (World Trade Organization, e.d.).

Nátengt hluthafasjónarmiðinu er sjónarmiðið, eða kenningin, um einhliða ávinning (e. win-lose) (Hoffman, 2000). Kenningin gengur út frá peirri forsendu að fyrirtækin geri sitt besta. Pví sé lítið svigrúm til umbóta á sviði umhverfismála. Auknar kröfur á sviði umhverfismála pýði aukinn tilkostnað og pví standi valið á milli efnahagslegra og umhverfislegra sjónarmiða eigi fyrirtæki að vera samkeppnishæf. Kenningin um einhliða ávinning felur í sér að ekki sé hægt að ná fram fjárhagslegum ávinningi samhliða umhverfislegum ávinningi, heldur verði annað sjónarmiðið að víkja (Hoffman, 2000). Af peim sökum verði umhverfismál undir par sem prýstingur hluthafa ræður för í rekstri fyrirtækja.

\subsection{Sjónarmið hagsmunaaðila og gagnkvæmur ávinningur}

Á undanförnum áratugum hefur áherslan á að hámarka arð hluthafa færst yfir í pað að tekið er mið af pörfum breiðari hóps hagsmunaaðila (Claver o.fl., 2007; Labuschagne, Brent, \& van Erck, 2005; Mygind, 2009). Fyrirtækjunum er nú ætlað að leysa vandamál sem pau skapa sjálf (Buchholz, 1991), til að mynda umhverfislegan skaða. Prýstingur frá hagsmunaaðilum (e. stakeholder pressure) um að fyrirtæki axli umhverfislega ábyrgð hefur aukist jafnt og pétt (Schaltegger \& Burritt, 2010). Á sjöunda áratug tuttugustu aldar voru helstu prýstihópar áhyggjufullir einstaklingar svo og stofnanir á sviði umhverfisverndar. Á áttunda áratugnum bættust í hópinn hluthafar, löggjafarvald, viðskiptavinir, birgjar, fjölmiðlar, keppinautar, vátryggingafélög, bankar, frjáls félagasamtök og aðgerðasinnar (GEMI, 1998; Hoffman, 2000; Maak, 2007). 
Samfélagsmiðlar auðvelda aðgang að upplýsingum um árangur fyrirtækja á sviði umhverfismála. Auðvelt er að dreifa upplýsingum um frammistöðu á Netinu. Samfélagsmiðlar eru og verða notaðir til að pröngva fyrirtæki til að starfa á pann hátt sem pykir ásættanlegt í samfélaginu (Jones, 2012). Fyrirtæki hljóta nú viðurkenningu fyrir að sýna umhverfisábyrgð í verki, eða fá skammir fyrir athafnaleysi eða aðgerðir sem leiða til umhverfislegs skaða (Hoffman, 2000; Porter \& Kramer, 2011). Gert er ráð fyrir að prýstingur á pessu sviði muni enn aukast vegna aukins prýstings á umhverfið vegna mannfjöldapróunar, lífshátta og umsvifa í atvinnulífinu. Niðursveifla í alpjóðlegu efnahagslífi hefur ekki hægt á pessari próun nema síður sé (Haanaes o.fl., 2011; KPMG International, 2011).

Eigi fyrirtæki að ná árangri til lengri tíma litið purfa pau að starfa í sátt við samfélagið sem gerir nú á dögum ráð fyrir pví að stjórnendur taki á samfélagslegum vanda, svo sem umhverfis- og loftslagsmálum, óháð stærð peirra og staðsetningu (Bonini, Hintz, \& Mendonca, 2008; Oppenheim o.fl., 2007; Porter \& Kramer, 2011). Af peim sökum eru umhverfis- og samfélagsleg málefni sampætt stjórnarháttum fyrirtækja (e. environmental, social and corporate governance) svo og stefnumörkun peirra og aðgerðum (Oppenheim o.fl., 2007). Leiðtogar fyrirtækja geta litið á pennan prýsting sem byrði eða sem tækifæri til að ná samkeppnislegu forskoti (Oppenheim o.fl., 2007). Í peim tilvikum par sem stjórnendur líta á umhverfismál sem tækifæri tengist hugsunin kenningum um gagnkvæman ávinning (e. win-win), pað er að umhverfisábyrgð feli samhliða í sér fjárhagslegan og umhverfislegan ávinning. Stjórnendur geta líka nálgast umhverfismál á stefnumarkandi hátt (e. environmental strategic perspective) en pá hagnýta fyrirtæki sér pau tækifæri sem felast í að axla umhverfisábyrgð, prátt fyrir útgjöld, til að ná auknu samkeppnisforskoti til lengri tíma litið (Hoffman, 2000).

\section{Rannsóknaraðferð}

Greinin byggir á doktorsritgerð Láru Jóhannsdóttur, eins af höfundum greinarinnar, sem framkvæmdi tilviksrannsókn (e. case study) (Yin, 2009) meðal 16 norrænna vátryggingafélaga, en félögin eru meðal stærstu vátryggingafélaganna á norræna vísu eða heimamarkaði. Vátryggingafélögunum var skipt upp í tvo hópa, eyjahóp sem í voru átta vátryggingafélög frá Álandseyjum, Færeyjum og Íslandi og meginlandshóp sem í voru átta vátryggingafélög frá Danmörku, Finnlandi, Noregi og Svíbjóð, sjá töflu 1.

Fyrirtækin í eyjahópnum teljast lítil (tvö fyrirtæki) eða meðalstór (sex fyrirtæki), en fyrirtækin í meginlandshópnum eru öll stór samkvæmt skilgreiningu Eurostat sé miðað við fjölda starfsmanna.

Alls voru tekin 74 viðtöl við stjórnendur og sérfræðinga, auk sex viðtala við utanaðkomandi sérfræðinga. Pá voru framkvæmdar sjö pátttökuathuganir. Viðmælendum í 
rannsókninni voru gefin ný nöfn til að halda trúnaði við pá, en vísað er til peirra undir dulnefnum í beinum tilvitnunum.

Tafla 1. Upplýsingar um fyrirtcki og viðmolendur.

\begin{tabular}{lccccc}
\hline $\begin{array}{l}\text { Fjöldi starfsfólks og } \\
\text { staðsetning fyrirtækja }\end{array}$ & $\begin{array}{c}\text { Fjöldi } \\
\text { starfsstöðva }\end{array}$ & $\begin{array}{c}\text { Viðtöl hjá } \\
\text { vátrygg- } \\
\text { ingafélögum }\end{array}$ & $\begin{array}{c}\text { Viðmælendur } \\
\text { innan vátrygg- } \\
\text { ingafélaga }\end{array}$ & $\begin{array}{c}\text { Fjöldi } \\
\text { pátttöku- } \\
\text { athugana }\end{array}$ & $\begin{array}{c}\text { Viðmælendur } \\
\text { utan vátrygg- } \\
\text { ingafélaga }\end{array}$ \\
\hline $\begin{array}{l}\text { Starfsfólk }<250 \\
\quad \text { Álandseyjar }\end{array}$ & 2 & 7 & 9 & 1 & 0 \\
$\begin{array}{l}\text { Færeyjar } \\
\text { Ísland }\end{array}$ & 2 & 6 & 6 & 0 & 0 \\
Starfsfólk<7.000 & 4 & 14 & 16 & 2 & 5 \\
Danmörk & 2 & 4 & 4 & 1 & 0 \\
Finnland & 2 & 9 & 10 & 1 & 0 \\
Noregur & 2 & 8 & 9 & 2 & 1 \\
Svípjóð & 3 & 14 & 20 & 0 & 0 \\
\hline Samtals & 17 & 62 & 74 & 7 & 6 \\
\hline
\end{tabular}

\subsection{Meðhöndlun og greining gagna}

Viðtölin fóru flest öll fram á ensku, fyrir utan viðtöl við íslenska stjórnendur og sérfræðinga, en pau viðtöl fóru fram á íslensku. Viðtölin voru hljóðrituð og skrifaðar voru vettvangsnótur fyrir hvert viðtal. Í vettvangsnótum voru skráðar upplýsingar um aðgang að viðkomandi fyrirtæki, lýsing á vettvangi og viðmælanda, athöfnum, hlutum, viðburðum tengdum viðtalinu, tímaröð, tilfinningu rannsakanda, viðtalið sjálft, brottför og hugleiðingar að viðtali loknu. Viðtölin voru afrituð frá orði til orðs og vistuð sem hluti af vettvangsnótum. Pá telja til rannsóknargagna rannsóknardagbók, greiningarblöð, gögn frá fyrirtækjum og fleira.

Notaðar voru mismunandi aðferðir við að greina gögnin, til dæmis opin kóðun og markviss kóðun. Notaðir voru lifandi kóðar (kóðar sem spruttu úr gögnunum) og tilbúnir kóðar (hugtök sem útbúin voru af rannsakanda). Hugarkort voru notuð til að halda utan um hugtök og pemu. Pemu sem fram komu voru flokkuð og undirflokkar útbúnir eftir pví sem við átti. Innihaldsgreining var einnig notuð og gerður var samanburður á kóðum milli viðtala í sama tilvikshópi og á milli tilvikshópa til pess að skoða hvort áherslur væru svipaðar eða hvort upp kæmu mótsagnir á milli tilvikshópa (Taylor \& Bogdan, 1998). 


\section{Niðurstöður rannsóknar}

Í eyja- og meginlandshópunum komu fram ólík viðhorf til umhverfismála. Í fyrri hópnum ræddu viðmælendur til dæmis um kostnað og fyrirhöfn vegna aðgerða á sviði umhverfismála. Pá komu fram efasemdir um að loftslagsbreytingar ættu sér stað, auk pess sem nefnt var að vátryggingafélögin brygðust við lagalegum kröfum fremur en að pau sýndu frumkvæði í að axla umhverfislega ábyrgð. Í meginlandshópnum var pessu öfugt farið en viðmælendur ræddu umhverfismál meðal annars út frá sparnaði og möguleikum fyrirtækja til að nýta umhverfismál til aðgreiningar frá keppinautum og par af leiðandi að skapa samkeppnisforskot. Einnig voru umhverfismál rædd út frá siðferðilegum sjónarmiðum og gildismati stjórnenda, en pessi afstaða komu ekki fram í eyjahópnum. Pessi ólíku sjónarmið til umhverfismála virðast hafa áhrif á aðgerðir eða aðgerðaleysi vátryggingafélaganna á sviði umhverfismála.

Einn páttur sem skýrir ólíka afstöðu til umhverfismála innan vátryggingafélaganna er stærð félaganna, sjá töflu 1. Í pessu samhengi er rétt að nefna að með fáum undantekningum töldu viðmælendur í eyjahópnum ekki að smæð fyrirtækjanna stæði í vegi fyrir aðgerðum á sviði umhverfismála, heldur fjölluðu peir um félögin sem fá og stór í samanburði við flest öll fyrirtæki á heimamarkaði, auk pess sem pau gætu sniðið sér stakk eftir vexti við innleiðingu á umhverfisábyrgð.

Aðrir pættir sem fram komu í rannsókninni og skýra mismunandi áherslur vátryggingafélaga á sviði umhverfismála voru til dæmis vitund eða skortur á vitund um umhverfismál og ólík viðhorf til umhverfismála. Pá var skammtímahugsun í rekstri vátryggingafélaganna í eyjahópnum sýnileg í gögnum par sem viðmælendur ræddu vandamál dagsins í dag svo sem innbrot, en viðmælendur í meginlandshópnum ræddu markmið og áherslur 10-30 ár fram í tímann. Einnig virðast skortur á sýnileika umhverfislegra vandamála og einangrun stjórnenda í eyjahópnum frá umræðunni sem á sér stað á meginlandinu hafa áhrif, en umræddir stjórnendur hafa til að mynda ekki tekið pátt í ráðstefnum norrænna vátryggingafélaga um loftslagsmál. Slíkar ráðstefnur voru haldnar árin 2008, 2009 og 2012.

\subsection{Viðhorf til umhverfismála í meginlandshópnum}

Viðhorf til umhverfismála í meginlandshópnum var almennt séð jákvætt og nefndu viðmælendur minni kostnað, auknar tekjur og tækifæri sem fælust í pví að horfa á umhverfismál sem leið til pess að draga úr rekstraráhættu eða auka samkeppnisforskot. Viðmælendur tengdu saman áherslur í umhverfismálum við rekstrarumhverfi vátryggingafélaganna. Umhverfismál og aðgerðir á pví sviði voru rædd út frá auðlindamálum, svo sem orku- eða hráefnisnotkun, úrgangs- og mengunarmálum sem og loftslagsbreytingum. Viðmælendur ræddu bein áhrif á rekstur vátryggingafélaganna og óbein 
áhrif í gegnum vátryggingasamninga við einstaklinga og fyrirtæki, samninga við birgja og fjárfestingar. Viðmælendur ræddu möguleika vátryggingafélaganna á að draga úr umhverfisáhrifum af eigin starfsemi. Sá páttur var talinn fremur veigalítill vegna eðli starfseminnar, en samt mikilvægur, meðal annars til að sýna gott fordæmi.

Viðmælendur ræddu einnig önnur óbein áhrif sem vátryggingafélög geta haft, en pau áhrif eru umtalsverð og felast í pví að ná fram jákvæðum umhverfislegum áhrifum í gegnum ýmsa hagsmunaaðila. Viðmælendur töldu vátryggingafélögin í góðri aðstöðu til að hafa áhrif á viðskiptavini, birgja, samstarfsaðila, stjórnvöld og fleiri hagsmunaaðila. Svo vitnað sé í Tom Anders Stenbro, sérfræðing á sviði samfélagsábyrgðar hjá vátryggingafélaginu Tryg pá útskýrir hann áherslur fyrirtækisins á sviði loftslagsmála (ClimateWise, e.d.) á eftirfarandi máta:

Fyrirtækið okkar bíður ekki bara og vonar eftir veröld par sem áhættunni af loftslagsbreytingum er vel stjórnað, heldur viljum við taka pátt í að skapa slíka veröld með beinum aðgerðum á pessu sviði sem felast í fjárfestingum, lausnum til viðskiptavina og með áhættustjórnun.

petta pýðir að framtíðarsýn fyrirtækisins er skýr; hvert pað stefnir, á hvaða sviði fyrirtækið getur lagt sitt af mörkum og hvaða aðgerðir hægt er að nota til pess að ná árangri. Hér er ekki eingöngu um skoðanir sérfræðingsins að ræða, heldur er í ýmsum skýrslum fyrirtækisins lýst raunverulegum aðgerðum pess á sviði umhverfis- og loftslagsmála. Par má til dæmis nefna samstarf vátryggingafélaganna If, Gjensidige, Codan/ Tryg-Hansa og Tryg við NORD-STAR, Nordic Centre of Excellence for Strategic Adaptation Research, við próun á hugbúnaðinum „VisAdapt“, sem ætlað er að hjálpa húseigendum að forðast tjón vegna loftslagsbreytinga (NORD-STAR, 2013). Samkvæmt yfirlýsingum Tom Anders, eru hagsmunir viðskiptavina einnig teknir hér inn í myndina, ekki bara hagsmunir fyrirtækisins og er sú yfirlýsing studd með aðgerðum fyrirtækisins á pessu sviði. Framtíðarsýn leiðtoga er talin vera mikilvæg:

Pú parft virkilega á einhverjum að halda sem segir: „Ég trúi á petta“ - og við höfum séð pað innan okkar hóps (Per Holmgreen).

Samvinna við aðra vátryggjendur eða aðra hagsmunaaðila er talin skila meiri árangri en ef félögin starfa hvert í sínu horni. Hjá viðmælanda frá vátryggingafélagi í Finnlandi kom fram að í sumum tilvikum notuðu stjórnendur fyrirtækja stranga löggjöf á sviði umhverfismála sem afsökun fyrir aðgerðaleysi:

Meðal sjónarmiða sem ég heyri er: Hvers vegna ættum við að innleiða samfélagslega ábyrgð? Löggjöf í Finnlandi er pegar svo ströng að hún stuðlar hvort tveggja í senn að ábyrgð fyrirtækja og sjálfbærni (Ilma Mikkonen). 
Slík sjónarmið eru í andstöðu við hugmyndafræði um samfélagsábyrgð sem gengur út frá pví að fyrirtæki gangi lengra en löggjöfin býður peim að gera. Árekstrar á milli gildismats fyrirtækja og einstaklinga eru skýrðir ágætlega í eftirfarandi tilvitnun:

Ég nota annars konar orð en pessi kostnaðarhlutföll ... mjög svo tæknilegu hagfræðihugtök. Ég nota CSR-orð [samfélagsábyrgð], annars konar orðaforða, en sem er að sama skapi partur af stefnu félagsins. Við störfum undir stífu fjárhagslegu aðhaldi pessa stundina. Fjárhagsáætlun hefur ekkert með gildismat að gera - hún er bara á ákvörðun. CSR og fjárhagsáætlun ættu að vera metin á sama máta, pað er að segja ef við höfum skuldbundið okkur til að innleiða CSR. Pað hefur ekkert með persónuleg gildi pín að gera, hvort pú framfylgir gildum fyrirtækisins pegar pú tekur ákvarðanir, vegna pess að ef pú gerir pað varðandi CSR pá mun ég gera slíkt hið sama varðandi fjárhagsáætlunina, pað er ég legg pau að jöfnu. Ef petta er hluti af stefnu okkar, pá hafa pessi atriði jafnt vægi, en hafa ekki með persónuleg gildi pín að gera. Ennfremur; mér líkar pað ekki pegar gildi eru talin óæðri peningum - pað er ekki gildi í mínum huga (Ilma Mikkonen).

Hjá Jones (2012) kemur fram að málið snúist um andstæða póla: „viltu græða peninga?“ (e. do you want to make money?) eða „viltu gera góða hluti?“ (e. do you want to do good?). Að öllu jöfnu eru fjárhagsleg sjónarmið talin mikilvægari en að „bjarga jörðinni“" sem byggir á gildismati einstaklinga. Petta endurspeglast í pví sem Sven Damgaard segir: „Við erum ekki jólasveinninn. Við purfum að græða peninga“, en er í mótsögn við pað sem Martin Enkvist hefur fram að færa, en báðir viðmælendurnir eru sérfræðingar í vátryggingafélögum á meginlandinu.

Ef pú útbýrð umhverfisstefnu, pá gerir pú pað ekki eingöngu til pess að græða peninga pví að pað er megintilgangur fyrirtækja. pú gerir pað vegna pess að pú vilt bæta umhverfið. Fyrir mér felst pversögn í pví að hafa umhverfisstefnu sem talin er vera óæðri fjárhagslegum sjónarmiðum. Ég tel pað óheppilegt pví að pað vill gleymast á mörgum sviðum fyrirtækja að fyrirtæki hafa annan og meiri tilgang en að græða peninga.

Lauri Sasi nefndi gildi sem innri hvata fyrir aðgerðum fyrirtækisins sem hann starfar hjá:

Pessa stundina snýst petta fyrst og fremst um gildi hjá fyrirtækinu; pað að við séum ábyrgur borgari, ábyrgt fyrirtæki, til pess að teljast trúverðug.

Ilma Mikkonen sagði að ef um er að ræða árekstra á milli persónulegra gilda og pess sem fyrirtækið vill standa fyrir, sé hætta á að grafið sé undan umræðunni. Máli sínu til stuðnings nefndi hún pegar brotist var inn í tölvukerfi East Anglia háskólans í Bretlandi og tölvupóstum starfsmanna lekið til fjölmiðla fyrir COP15-ráðstefnuna í Kaupmannahöfn í desember 2009 í pví skyni að skaða umræðu um neikvæð áhrif loftslagsbreytinga. Málið var blásið upp í fjölmiðlum undir nafninu Climategate og talað um að vísindamenn væru að falsa niðurstöður varðandi alvarleika loftslagsbreytinga. 
Pannig var reynt að grafa undan trausti á loftslagsvísindum. Fjölmiðlaumræðan gekk meðal annars út á að afneita loftslagsbreytingum, prátt fyrir að ekki kæmu fram gögn sem sýndu fram á að staðhæfingar af pessum toga stæðust (Sveinn Atli Gunnarsson, e.d.).

Peir koma upp á yfirborðið eftir að hafa fundið pessa ómerkilegu tölvupósta einhvers staðar. Ég er bara að segja að pegar eitthvað slíkt gerist, pá er mjög áhugavert að sjá hvað kemur upp á yfirborðið, pú veist hvers konar viðhorf og athugasemdir koma fram.

Pú lendir í ótrúlegustu umræðum um pessi mál. Tökum sem dæmi pessi opinberu skjöl um loftslagsbreytingar [IPCC-skýrslurnar]. Einhver finnur smávægileg mistök og getur jafnvel ekki sett pau í eðlilegt samhengi [e. scale it to the right proportion] af pví að petta er svo ómerkilegt og skiptir nákvæmlega engu máli. En engu að síður, byggt á ómerkilegum smáatriðum, byrjar fólk að segja: „Sjáðu - skýrslurnar eru einskis virði“. Hvernig í ósköpunum eigum við að finna lausn á vandamálunum ef petta er kjarni umræðunnar? (Ilma Mikkonen).

Í einu af meginlandsfélögunum sem hefur verið að móta sér stefnu á sviði samfélagslegrar ábyrgðar var ekki átakalaust að breyta ríkjandi hugsunarhætti.

Við höfum aldrei haft skoðanir af pessum toga. Eina skoðunin sem við höfum haft er að græða meira en við gerðum í fyrra. Ég held að pað sé úrelt hugsun. Starfsmenn munu ekki sampykkja slíkt. Peir vilja ekki hefja störf hjá fyrirtæki sem gengur eingöngu út á að græða meiri fjármuni en í fyrra (Morten Nielsen).

Viðmælendur nefndu einnig fyrirtæki sem skara fram úr eins og til dæmis NovaNordisk, en tilgangur fyrirtækisins er að útrýma sykursýki, pó svo að undirliggjandi hvati sé vissulega fjárhagslegs eðlis. Viðmælendur töldu einnig að ávinningur fyrirtækja fælist í pví að halda góðu starfsfólki og laða að nýtt starfsfólk.

Ég held að fyrirtæki purfi að átta sig á pví að ef pau ætla að ráða ungt fólk pá vill pað geta samsamað sig við gildi fyrirtækisins og siðareglur. Petta snýst ekki bara um laun, heldur einnig siðferði og hvað við stöndum fyrir. Fyrirtæki geta notað pess háttar áherslur til að markaðssetja sig sem fyrirtæki sem hugsar vel um starfsfólk og umhverfi og starfar samkvæmt siðferðilegum sjónarmiðum (Kasper Landquist).

Рað var mat viðmælenda að starfið sjálft, eða pað að skila arði til hluthafa, væri ekki nóg til að stuðla að starfsánægju heldur væri æðri tilgangur með rekstrinum pýðingarmikill. Rasmus Lund útskýrði muninn á leiðandi fyrirtækjum á sviði samfélagslegrar ábyrgðar og peim sem væru eftirbátar. Leiðandi fyrirtæki litu á samfélagsleg málefni sem tækifæri, en eftirbátarnir litu á pau sem rekstraráhættu.

Pá nefndu viðmælendur að verðmætasköpun tengdist vörumerkinu og ímynd, bæði ímynd fyrirtækja almennt og ímynd fyrirtækja sem vinnuveitenda, og að vörumerkið tengist framtíðarsýn fyrirtækja sem studd sé fyrirtækjamenningunni. Tina 
Madsen vék að stolti af pví að vinna hjá samfélagslega ábyrgu fyrirtæki og að sá páttur kæmi til álita pegar fólk veldi sér vinnuveitanda. Рað væri gefandi að vinna hjá fyrirtæki par sem persónuleg gildi og gildi fyrirtækisins færu saman, pví pá teldi starfsfólk að framlag peirra skipti máli, ekki bara fyrir fyrirtækið heldur fyrir samfélagið í heild.

раð kom fram í viðtölum að pað væri vissulega auðveldara fyrir fyrirtæki að innleiða aðgerðir ef fjárhagsleg og umhverfisleg sjónarmið færu saman. Einnig kom fram að sjónarmið gætu breyst eftir pví sem vitund um umhverfisleg vandamál eykst. Í upphafi væri útgangspunkturinn að spara fjármuni, til dæmis við að endurnýta varahluti í bíla, en síðar kæmu fram jákvæð umhverfisleg áhrif af aðgerðunum sem pýddu að fyrirtækin héldu verkefnum áfram vegna fjárhagslegra og umhverfislegra ástæðna.

\subsection{Viðhorf til umhverfismála í eyjahópnum}

Svör viðmælenda í eyjahópnum voru á pann veg að vátryggingafélögin væru skammt á veg komin í umhverfismálum. Pegar viðtölin voru tekin (2009 og 2010) hafði ekkert vátryggingafélaganna sett sér umhverfisstefnu eða tengdar stefnur, pó að fyrirmyndir mætti finna víða. Pví má segja að stefnuleysis hafi gætt á sviði umhverfismála. Pó kom fram í máli Erlu Jónsdóttur að „pað megi vera að félagið hafi einhvern tímann sett fram umhverfisstefnu“, en ljóst má vera að umhverfisstefna gerir lítið gagn ofan í skúffu.

Nýleg skoðun á vefsíðum hérlendra vátryggingafélaga leiðir í ljós að finna má einhverjar áherslur á sviði umhverfismála og dæmi um aðgerðir, en enn sem komið er hefur ekkert íslenskt vátryggingafélag birt formlega umhverfisstefnu eða umhverfis-, samfélags- eða loftslagsskýrslu sem útfærir aðgerðir, tiltekur mælanleg markmið og/eða sýnir fram á árangur á pessu sviði.

VÍS leggur áherslu á að starfsemi félagsins stuðli að sem minnstri mengun, hreinni náttúru og förgun úrgangs í kjölfar tjóna á sem umhverfisvænastan máta (Vátryggingafélag Îslands hf., e.d.).

TM býður eigendum vistvænna ökutækja lægri iðgjöld og TM er styrktaraðili Græns apríls, verkefnis áhugafólks um umhverfismál (Tryggingamiðstöðin, e.d.).

Pegar rætt var um umhverfismál var flokkun pappírs eitt af peim málefnum sem fyrst kom upp hjá viðmælendum. Í sumum tilvikum, sér í lagi á Íslandi og í Færeyjum, var umræðan neikvæð og var litið á umhverfismál sem „mjúk mál“, en ekki pætti sem skipta máli varðandi rekstur fyrirtækjanna. Viðmælendur notuðu hugtök eins og „soft issue“ og „lúxusvandamál“ pegar peir ræddu umhverfismál. Pá var talað um að verkefnin af pessum toga væru „neðarlega á forgangslistanum“, pau væru á „hliðarlínunni“ og teldust til „gæluverkefna“, fremur en að um væri að ræða brýn úrlausnarefni, verkefni sem gætu skilað fyrirtækjunum fjárhagslegum arði eða dregið úr rekstraráhættu peirra. Viðmælendur tengdu umhverfismál við útgjöld og aukna fyrirhöfn. Pá komu 
fram í viðtölum pau sjónarmið að vátryggingafélög væru ekki í mengandi starfsemi og par af leiðandi vægju umhverfismál ekki pungt pegar kæmi að viðskiptaákvörðunum og aðgerðum. Horft var fram hjá umhverfisáhrifum af tjónum, en pau geta verið umtalsverð, sér í lagi á sviði eigna- og ökutækjatjóna, sem og umhverfislegri áhættu sem fram getur komið í vátryggingasamningum við fyrirtæki eða einstaklinga. Sjónarmið eigenda komu pví mun skýrar fram, en sjónarmið breiðs hóps hagsmunaaðila pegar umhverfismál voru rædd.

Pað væri náttúrulega hroki að segja að pau [umhverfisáhrifin] skipti ekki máli, en ég get alla vega sagt að pau skipta ekki meira máli en svo að pau hafa eiginlega aldrei verið til umræðu (Jóhann Gunnarsson).

Vörurnar okkar eru óápreifanlegar par sem við seljum öryggi og öryggistilfinningu (Jákup Jakopsen).

Í innkaupastefnum eru oft settar fram áherslur varðandi vistvæn innkaup, en að sögn viðmælenda hafa hérlendu vátryggingafélögin ekki skjalfestar innkaupastefnur. Í slíkum stefnum er til dæmis tekið á vali á umhverfismerktum vörum, vali á raftækjaog tölvubúnaði sem hlotið hefur vottun fyrir orkunýtingu fram yfir aðrar sambærilegar vörur, kröfur til birgja og pess háttar. Pá horfa fyrirtæki til líftímakostnaðar við kaup og rekstur á vörum í stað pess að horfa eingöngu á stofnkostnað. Innkaupastefna sem tekur á umhverfislegum páttum er ekki til staðar hjá vátryggingafélögunum og varðandi vistvæn innkaup nefnir Jóhann Gunnarsson að:

pað geti vel verið að stelpurnar í eldhúsinu séu að kaupa og spá í pað, en ég pekki pað ekki.

Sama gilti um fjárfestingastefnur sem taka á fjárfestingatækifærum í umhverfisvænum lausnum, slíkar stefnur eru ekki til staðar. Smæð fyrirtækja er einnig hugsanleg hindrun, pað er að vátryggingafélög hér á landi eru sein að taka við sér pegar kemur að umhverfismálum. Ágúst orðar pað pannig:

að mínu mati eru íslensk vátryggingafélög skemur á veg komin í flestum páttum starfseminnar heldur en tryggingafélög á Norðurlöndum ... við erum bara nokkrum árum á eftir, pað verður bara að segjast eins og pað er.

Förgun á tölvu- og raftækjabúnaði kom ekki til umræðu nema hvað Ágúst Bjarnason nefndi að „við purfum að passa pegar við skiptum um tölvuskjái að peir fari ekki í ruslið“. Pegar leið undir lok viðtalstímabilsins höfðu vátryggingafélögin undirritað samkomulag við Græna framtíð um söfnun og meðhöndlun raftækjaúrgangs, en meðhöndlun á úrgangi byggir á lögum nr. 55/2003 með áorðnum breytingum. Fyrirtæki eru pví ekki að fara umfram pað sem lög bjóða með slíkum samningum, en sam- 
félagsleg og/eða umhverfisleg ábyrgð miðar að pví fyrirtæki axli ábyrgð umfram pað sem lög skylda.

Aðrar aðgerðir sem viðmælendur nefndu voru almennt séð smáar í sniðum, án stefnumarkandi áherslna og/eða settar fram í peim tilgangi að spara kostnað og par af leiðandi að bæta hag eigenda. Par má nefna sem dæmi rafræna útsendingu gagna, flokkun á pappír og endurvinnslu, auk pess sem hætt var að nota plastmöppur utan um tjónaskýrslur og keramikkönnur keyptar í stað plastmála.

pegar viðmælendur voru spurðir að pví hvort pað væru einhverjar hindranir í vegi fyrir pví að vátryggingafélög beittu áhrifum sínum til lausnar á umhverfislegum vandamálum voru svörin á pann veg að hindranir væru ekki til staðar, hvorki lagalegar né af öðrum toga. Einnig kom fram að petta væri „meira svona ákvörðun“ og „kúltúr“ fyrirtækjanna. Menning getur hindrað frampróun fyrst umhverfisvitund hefur ekki náð að síast inn í fyrirtækjamenningu íslenskra vátryggingafélaga. Lítil pekking á umhverfis- og loftslagsmálum í tengslum við rekstur vátryggingafélaga virðist einnig vera hindrun og viðmælendur almennt lítið farnir að velta fyrir sér hvort og pá hvaða áhrif pessir pættir gætu haft á rekstur vátryggingafélaganna.

ég fagna ekki gróðurhúsaáhrifum, en pau geta auðvitað haft pau áhrif að hérna séu mildari vetur og pá minni hálka (Ágúst Bjarnason).

Hækkun á sjávaryfirborði mun ekki [hafa áhrif], við myndum [geta] flutt höfuðstöðvarnar. Við myndum bara purfa að flytja pær einhverja metra upp á við. Ég tel ekki að Færeyjar verði fyrir áhrifum, jafnvel pó að yfirborðið hækki um 2 metra (Signar Samúelsson).

Pá kom fram að fólki pótti umræðan um málefni eins og loftslagsbreytingar vera óskýr og að fullar sönnur væru ekki komnar fram. Einnig komu fram pær efasemdir sem Ilma Mikkonen minntist á.

Að mínu mati snýst petta um trú. Hverju pú trúir, vegna pess að sönnunargögnin stangast á, skýrslur eru misvísandi, og pví er petta spurning um pað hvað pú trúir á (Magni Mortensen).

Ég heyrði í útvarpinu áðan að [loftslagsbreytingar] væru stórlega ýktar (Lilja Kristjánsdóttir).

Umhverfismál selja ekki í augnablikinu í Færeyjum (Signar Samuelsen).

Mildari vetur geta aukið fjölda hálkuslysa, pað er ef hitastig er oft um frostmark. Skýfall, asahláka og djúpar lægðir geta einnig aukið á tjónatíðni og kostnað sem vátryggingafélögin munu bera. Sumir viðmælendurnir sögðu pað hreint út að peir væru almennt lítið farnir að velta pessum málum fyrir sér. Einnig kemur fram, til dæmis í viðtalinu við Sigurð Pálsson, að vátryggingafélög hér á landi séu frumkvæðalítil. Pað sé helst að pau taki við sér „pegar einhver lagasetning hefur átt sér stað. Pá er 
að bregðast við henni“. Breytingar vátryggingaskilmála í tengslum við lög um mengun hafs og stranda var tekið sem dæmi um slík viðbrögð.

Á Álandseyjum var vitund og viðhorf til umhverfismála af öðrum toga en í Færeyjum og á Íslandi, en par brenna umhverfismál meira á eyjaskeggjum og vandamálin eru sýnileg með berum augum, auk pess sem ólykt berst að vitum íbúa. Fyrsta tilvitnunin hér að neðan er í viðmælanda frá Álandseyjum, en síðari tvær í viðmælendur í Færeyjum.

Við lifum nálægt sjávarmáli. pú getur séð [vandamálin] með eigin augum á sumrin. Pá sést af og til græn slikja [á sjónum] og veiði hefur dregist saman frá pví sem áður var (Kaj Sundberg).

Við búum á pessum grænu eyjum umluktum heimsins hreinasta sjó. Við hugsum bara um að halda honum hreinum. Við höfum sterk tengsl við náttúruna (Gunnvá Joansen).

Jafnaldrar okkar í Færeyjum hafa flestir hverjir búið erlendis. Pegar við snúum aftur, pá erum við í umhverfislegri paradís (Signar Samuelsen).

Fram kom hjá Ásdísi Guðmundsdóttur að vátryggingareksturinn væri i járnum. Nokkrir viðmælendanna nefndu að vátryggingamarkaðurinn væri mjög verðdrifinn og að pað væru litlar líkur á að viðskiptavinir veldu tryggingafélag á grundvelli umhverfissjónarmiða heldur stýrði verð hegðun viðskiptavina. Petta er í andstöðu við sjónarmiðið sem fram kom hjá meginlandsfélögum sem töldu að hægt væri að nota samfélagslegar áherslur til aðgreiningar frá keppinautunum. Viðmælendur gáfu sér almennt pær forsendur að umhverfismál fælu í sér aukinn kostnað og að umhverfismál myndu par af leiðandi ekki eiga upp á pallborðið í pví efnahagsástandi sem nú ríkir.

Færeyingar vöknuðu upp við vondan draum í nóvember 2011 pegar fellibylurinn Berit gekk á land og olli gríðarlegri eyðileggingu, en pök fuku af húsum, bátar slitnuðu frá bryggjum og rak á land eða sukku, bílar skemmdust og lausir munir fuku um (DV, 2011). Vegna gríðarlegs eignatjóns fór fram fjársöfnun á Íslandi (Vísir, 2011). Pegar viðtölin fóru fram voru viðburðir af pessum toga ekki áhyggjuefni viðmælenda.

Pað eru í raun bara stormar í flokknum 4 eða 5 sem fá athygli hér. Slíkir stormar eru í lagi.

Við förum bara inn og bíðum par til peir eru yfirstaðnir (Signar Samuelsen).

Ein peirra skýringa sem viðmælendur gáfu á pví að umhverfismál hefðu ekki fengið mikla athygli innan félaganna var skortur á prýstingi frá ytri öflum, til að mynda löggjafarvaldinu og viðskiptavinum. Viðmælendur töldu sumir hverjir að umhverfisvitund viðskiptavina væri minni en hjá öðrum norrænum vátryggingafélögum sem pýddi að prýstingur á vátryggingafélögin væri ekki til staðar. Pá komu fram hugleiðingar um pað hvort hugsanleg innganga í Evrópusambandið myndi hraða breytingum á sviði umhverfis- og loftslagsmála hér á landi, en Anna Jóhannsdóttir orðaði pað 
pannig: „pá munum við fyrr verða meðvitaðir og jafnvel vera krafist meira af okkur en ella“. Pessu til stuðnings var bent á að EES-samningurinn hefði sett pressu á Íslendinga um að taka til hendinni í úrgangsmálum.

\section{Umræður}

Tilgangur rannsóknarinnar var að skoða hvort mismunandi viðhorf til umhverfismála komi fram í tilvikshópum rannsóknarinnar, á hvern hátt pessi viðhorf tengjast hluthafa- og haghafakenningum og hvort viðhorfin hafi hugsanleg áhrif á aðgerðir eða aðgerðaleysi á sviði umhverfismála. Í rannsókninni koma fram vísbendingar um að svo sé. Helstu niðurstöður eru dregnar saman í töflu 2, par sem gerður er samanburður á milli tilvikshópa.

Tafla 2. Samanburður á milli tilvikshópa.

\begin{tabular}{|c|c|c|}
\hline & Eyjahópur & Meginlandshópur \\
\hline Stefna í umhverfismálum & & (3) \\
\hline Stefnuleysi í umhverfismálum & (3) & \\
\hline Ytri hvatar & (7) & (7) \\
\hline Innri hvatar & & (7) \\
\hline Jákvætt viðhorf til umhverfismála & & (7) \\
\hline Neikvætt viðhorf til umhverfismála & (7) & \\
\hline Einhliða ávinningur (win-lose) & (7) & \\
\hline Gagnkvæmur ávinningur (win-win) & & (7) \\
\hline Hluthafakenning & (7) & \\
\hline Haghafakenning & & (7) \\
\hline
\end{tabular}

Í eyjahópnum gætti stefnuleysis í umhverfismálum, viðmælendur sögðust ekki finna fyrir ytri prýstingi nema helst lagalegum, viðhorf til umhverfismála var fremur neikvætt, og sjónarmið um einhliða fjárhagslegan ávinning á kostnað umhverfisins var áberandi. Slík sjónarmið eru talin tengjast kenningum um hag eigenda eða hluthafa (Friedman, 1970; Oppenheim o.fl. 2007; Smith, 2007) umfram hag víðari hóps hagsmunaaðila (Claver o.fl., 2007; Labuschagne, Brent, \& van Erck, 2005; Mygind, 2009). Í meginlandshópnum höfðu fyrirtækin markað sér umhverfis- og/eða loftslagsstefnur, pau fundu fyrir ytri prýstingi, auk pess sem innri hvatar um fjárhagslegan ávinning og siðferðileg sjónarmið komu par fram (sjá til dæmis Bansal \& Roth, 2000; Jones, 2012; Tutore, 2010; Wood, 1991). Viðhorf til umhverfismála var almennt jákvætt, og var meðal annars rætt út frá sparnaði og tækifærum, en slík sjónarmið um gagnkvæman ávinning eru tengd hugmyndum um hag breiðs hóps hagsmunaaðila (Ardichvili, o.fl., 
2009; European Commission, 2011; International Organization for Standardization, 2011).

Til pess að svara rannsóknarspurningunum má í skemmstu máli segja að svarið við spurningunni „Hvað einkennir viðhorf stjórnenda og sérfræðinga í norrænum vátryggingafélögum til umhverfismála?"“ sé að viðhorfið sé fremur neikvætt í eyjahópnum en jákvætt í meginlandshópnum. Gildismat og framtíðarsýn stjórnenda virðist hafa hér sitt að segja. Sjónarmiðin eru allt frá pví að viðmælendur segist „trúa á petta“ til pess að „stelpurnar í eldhúsinu“ beri hugsanlega ábyrgð á pessum málaflokki. Pau sjónarmið sem Ardichvili o.fl. (2009) settu fram - tilgangur og gildismat, jafnvægi á milli hagsmunaaðila, forysta, starfshættir og langtímasjónarmið - komu ekki fram í eyjahópnum. Pessi sjónarmið eru talin stuðla að siðrænni fyrirtækjamenningu sem meðal annars stuðlar að pví að fyrirtæki axli umhverfislega ábyrgð. Sjónarmið Ardichvili o.fl. (2009) komu aftur á móti fram í viðtölum við starfsmenn og stjórnendur í meginlandshópnum.

Pegar litið er á rannsóknarspurninguna „Má útskýra mismunandi viðhorf til umhverfismála í mismunandi tilvikshópum með hluthafa- og haghafakenningum?" má sjá að viðhorf viðmælenda í eyjahópnum eru meira í takt við hluthafakenningar um hámörkun á hag hluthafa (Friedman, 1970) og sjónarmið um einhliða ávinning (Hoffman, 2000). Pað má meðal annars sjá á áherslum um kostnað og fyrirhöfn, að umhverfismál séu neðarlega á forgangslistanum og að aðgerðir séu settar fram í peim tilgangi að draga úr kostnaði sem leiðir til betri afkomu fyrir eigendur eða hluthafa. Haghafasjónarmið (Claver o.fl., 2007; Labuschagne o.fl., 2005; Mygind, 2009; Schaltegger \& Burritt, 2010) og sjónarmið um gagnkvæman ávinning (Hoffman, 2000) og æðri tilgang með rekstrinum eru mun sýnilegri í svörum viðmælenda í meginlandshópnum. Áherslur meginlandshópsins eru í takt við áherslur Evrópusambandsins um samfélagslega ábyrgð, stefnur og sjónarmið hagsmunaaðila (European Commission, 2011) og áherslur settar fram í ISO 26000 staðlinum (International Organization for Standardization, 2011), en áherslur eyjahópsins eru pað ekki. Ytri hvatar pvinga fyrirtæki til aðgerða. Fyrirtæki sem sýna frumkvæði og vinna sjálfviljug að úrlausn umhverfislegra vandamála og hagnýtingu tækifæra gera pað vegna innri hvata, pað er fjárhagslegra hvata eða siðrænna sjónarmiða (Bansal \& Roth, 2000; Mygind, 2009; Porter \& van der Linde, 1995; Tutore, 2010). Siðferðileg sjónarmið varðandi reksturinn (Bansal \& Roth, 2000; Cambra-Fierro, o.fl., 2008; Tutore, 2010) komu ekki fram í eyjahópnum, en komu fram í meginlandshópnum, til að mynda ábyrgð vátryggingafélaga gagnvart viðskiptavinum og samfélaginu - en ekki eingöngu að skila hagnaði til hluthafa.

Pegar dregin eru fram svör við rannsóknarspurningunni „Hvernig endurspeglast viðhorf til umhverfismála í aðgerðum eða aðgerðaleysi vátryggingafélaga?“ kemur í ljós 
að stefnuleysi í umhverfismálum einkennir fyrirtæki í eyjahópnum, öfugt við pað sem fram kemur í meginlandshópnum par sem áherslur í umhverfismálum eru álitnar veita samkeppnisforskot á markaði par sem boðnar eru sambærilegar vörur á sambærilegu verði. Umhverfislegar áherslur eru pví tengdar stefnumarkandi sjónarmiðum í viðkomandi fyrirtækjum. Aðgerðir í eyjahópnum eru smáar í sniðum, settar fram til að bregðast við lagasetningu, skammtímasjónarmið ráða ríkjum og verkefnin eru „á hlíðarlínunni“ (án tengsla við stefnu viðkomandi fyrirtækja). Smæð fyrirtækjanna í eyjahópnum getur skýrt pað að enn sem komið er gætir stefnuleysis á sviði umhverfismála, aðgerðir eru ómarkvissar og skila takmörkuðum umhverfislegum ávinningi. Í meginlandshópnum er fjallað um umhverfismál í víðara samhengi og pau rædd út frá ávinningi í eigin rekstri, minni rekstraráhættu og kostnaði, auknum tekjum, vátryggingasamningum, samningum við birgja, fjárfestingum og fleira. Niðursveifla í alpjóðlegu efnahagslífi hefur ekki hægt á peirri próun að fyrirtæki axli umhverfislega ábyrgð, nema síður sé (Haanaes o.fl., 2011; KPMG International, 2011). Ekki kom fram hjá viðmælendum á meginlandinu að efnahagslegt ástand drægi úr áherslum fyrirtækjanna á pessu sviði, en í sumum tilvikum kom slíkt upp í viðtölum við hérlenda viðmælendur. Í reynd má pví segja að íslensk vátryggingafélög, sem og önnur vátryggingafélög í eyjahópnum, hafi enn sem komið er ekki fylgt peirri próun á sviði umhverfismála sem á sér stað á meginlandinu.

Rannsóknir á sviði umhverfismála og fyrirtækjarekstrar eru nýjar af nálinni hér á landi. Î pessari rannsókn var ástand mála skoðað í einni iðngrein, samaborið við ástand mála hjá allmörgum norrænum vátryggingafélögum. Tækifæri felast í pví að skoða aðrar iðngreinar á svipaðan máta, pað er að kanna viðhorf og vitund til umhverfismála, stefnu, stefnuleysi, aðgerðir, aðgerðaleysi og svo framvegis, par sem vænta má aukins prýstings á aðgerðir fyrirtækja á pessu sviði á komandi árum og áratugum (OECD, 2012; Yoder, Rao, \& Bajowala, 2012). Í ljósi pess að rannsóknin sýnir mun milli tilvikshópa, er nauðsynlegt að setja framtíðarrannsóknir í stærra samhengi en pví sem fæst pegar ástand mála er eingöngu skoðað hér á landi.

Samkvæmt niðurstöðum rannsóknarinnar má leiða að pví líkum, á sama hátt og Bansal og Roth (2000) og Tutore (2010) hafa gert, að tengsl gildismats leiðtoga og siðferðilegra hvata (Bansal \& Roth, 2000; Tutore, 2010) hafi áhrif á frumkvæði fyrirtækja í umhverfismálum. Rannsóknin leiðir einnig í ljós að vitund um umhverfismál og viðhorf til umhverfismála virðist hafa áhrif á frumkvæði fyrirtækja í umhverfismálum. Par sem vitund um umhverfismál í tengslum við rekstur fyrirtækja er takmörkuð og viðhorf til aðgerða neikvæð parf að byrja á pví að efla vitund um umhverfismál og hvaða áhrif pau munu hafa á rekstrargrundvöll fyrirtækja í náinni framtíð (OECD, 2012; Yoder, Rao, \& Bajowala, 2012). Pað má til dæmis gera með sameiginlegu fræðsluátaki innan viðkomandi iðngreinar. Samtök fjármálafyrirtækja væri ef til vill heppilegur 
vettvangur fyrir vátryggingafélög hér á landi til pess að hefja umræður um málaflokkinn. Einnig má hugsa sér aukið samstarf við ýmis samtök fjármálafyrirtækja á Norðurlöndum, pannig að efla megi pekkingu innan íslenskra vátryggingafélaga á umræddu sviði, sem síðar getur leitt til aðgerða með jákvæðum áhrifum á reksturinn, samfélagið og umhverfið.

\section{Um höfundana}

Lára Jóhannsdóttir er nýdoktor við viðskiptafræðideild Háskóla Íslands. Netfang: laraj@hi.is. Snjólfur Ólafsson er prófessor við viðskiptafræðideild Háskóla Íslands og Brynhildur Davíðsdóttir er prófessor við líf- og umhverfisvísindadeild Háskóla Îslands. Grein pessi er byggð á óbirtri doktorsritgerð Láru Jóhannsdóttur, „Nordic non-life insurers' interest in, and response to, environmental issues“ sem varin var við Háskóla Íslands árið 2012. İ doktorsritgerðinni er ítarlegur listi með peim sjóðum og stofnunum sem styrktu rannsóknina. Greinin var kynnt á Pjóðarspegli Félagsvísindastofnunar Háskóla Îslands pann 28. október 2013.

\section{Heimildaskrá}

Ardichvili, A., Mitchell, J.A., \& Jondle, D. (2009). „Characteristics of ethical business cultures.“ Journal of Business Ethics, 85, 445-451. http://dx.doi.org/10.1007/s10551-008-9782-4

Bansal, P., \& Roth, K. (2000). „Why companies go green: A model of ecological responsiveness.“ Academy of Management Journal, 43, 717-736. http://dx.doi.org/10.2307/1556363

Bonini, S.M.J., Hintz, G., \& Mendonca, L.T. (2008). „Addressing consumer concerns about climate change." McKinsey Quarterly, 2008, 52-61.

Buchholz, R. A. (1991). „Corporate responsibility and the good society: From economics to ecology.“ Business Horizons, 34, 19-31. http://dx.doi.org/10.1016/0007-6813(91)90003-E

Cambra-Fierro, J., Hart, S., \& Polo-Redondo, Y. (2008). „Environmental respect: Ethics or simply business? A study in the small and medium enterprise (SME) context." Journal of Business Ethics, 82, 645-656. http://dx.doi.org/10.1007/s10551-007-9583-1

Claver, E., López, M.D., Molina, J.F., \& Tarí, J.J. (2007). „Environmental management and firm performance: A case study." Journal of Environmental Management, 84, 606-619. http://dx.doi.org/10.1016/j.jenvman.2006.09.012

ClimateWise (e.d.). Reducing the risk for tomorrow. London: ClimateWise. Vefslóð: www.climatewise.org.uk/storage/climatewise-docs/ClimateWise\%20brochure.pdf

DV (2011, 25. nóvember). „,Gerum allt sem við getum fyrir Færeyinga. “ "Vefslóð: www.dv.is/frettir/2011/11/25/gerum-allt-sem-vid-getum-fyrir-faereyinga/

Elkington, J. (1994). Towards the sustainable corporation: Win-win-win business strategies for sustainable development. California Management Review, 36, 90-101. http://dx.doi.org/10.2307/41165746

Ernst \& Young \& Oxford Analytica (2009). The 2009 Ernst \& Young business risk report: The top 10 risks for global business. EYGM Limited. 
Ernst \& Young \& Oxford Analytica (2010). The top 10 risks for business: A sector-wide view of the risks facing businesses across the globe. London: EYGM Limited.

European Commission (2011). „Corporate Social Responsibility (CSR). "Vefsíða. Sótt 26. nóvember $2013 \mathrm{af} \mathrm{http://ec.europa.eu/enterprise/policies/sustainable-business/}$ corporate-social-responsibility/index_en.htm

Friedman, M. (1970). „The social responsibility of business is to increase its profits.“ New York Times Magazine, 13. september.

GEMI (1998). Environment: Value to business. Washington: Global Environmental Management Initiative. Vefslóð: www.gemi.org/resources/EVTB_001.pdf

GEMI (2004). Clear advantage: Building shareholder value. Washington: Global Environmental Management Initiative. Vefslóð: www.gemi.org/resources/gemi clear advantage.pdf

Grojean, M.W., Resick, C.J., Dickson, M.W., \& Smith, D.B. (2004). „Leaders, values, and organizational climate: Examining leadership strategies for establishing an organizational climate regarding ethics." Journal of Business Ethics, 55, 223-241. http://dx.doi.org/10.1007/s10551-004-1275-5

Guidi, M.G.D., Hillier, J., \& Tarbert, H. (2008). „Maximizing the firm's value to society through ethical business decisions: Incorporating ,moral debt' claims." Critical Perspectives on Accounting, 19, 603-619. http://dx.doi.org/10.1016/j.cpa.2007.01.003

Haanaes, K., o.fl. (2011). Sustainability: The 'embracers' seize advantage. MIT Sloan Management Review Research Report, winter 2011. Boston: MIT Sloan Management Review og The Boston Consulting Group. Vefslóð: c0426007.cdn2.cloudfiles.rackspacecloud.com/

MIT-SMR-BCG-sustainability-the-embracers-seize-advantage-2011.pdf

Hemingway, C.A. (2005). „Personal values as a catalyst for corporate social entrepreneurship.“ Journal of Business Ethics, 60, 233-249. http://dx.doi.org/10.1007/s10551-005-0132-5

Hoffman, A.J. (2000). Competitive environmental strategy: A guide to the changing business landscape. Washington: Island Press.

International Organization for Standardization (2011). „ISO 26000 - Social responsibility“ (vefsíða). Sótt 20. desember 2011 af http://www.iso.org/iso/social_responsibility

Jones, D. (2012). Who cares wins: Why good business is better business. Harlow: Pearson Education Limited.

Jones, T.S. (1991). Ethical decision making by individuals in organizations: An issue-contingent model. The Academy of Management Review, 16, 366-395. http://dx.doi.org/10.2307/258867

KPMG International (2011). Corporate sustainability: A progress report. Vefslóð: www.kpmg.com/ Global/en/IssuesAndInsights/ArticlesPublications/Documents/corporate-sustainability-v2.pdf

Labuschagne, C., Brent, A.C., \& van Erck, R.P.G. (2005). „Assessing the sustainability performances of industries." Journal of Cleaner Production, 13, 373-385.

http://dx.doi.org/10.1016/j.jclepro.2003.10.007

Maak, T. (2007). „Responsible leadership, stakeholder engagement, and the emergence of social capital.“ Journal of Business Ethics, 74, 329-343. http://dx.doi.org/10.1007/s10551-007-9510-5

Mills, E. (2007). From risk to opportunity: 2007: Insurer responses to climate change. Boston: Ceres. Vefslóð: insurance.lbl.gov/opportunities/risk-to-opportunity-2007.pdf

Mills, E. (2009). From risk to opportunity: 2008: Insurer responses to climate change. Boston: Ceres. Vefslóð: insurance.lbl.gov/opportunities/risk-to-opportunity-2008.pdf 
Montiel, I. (2008). „Corporate social responsibility and corporate sustainability: Separate pasts, common futures. "Organization \& Environment, 21, 245-269.

http://dx.doi.org/10.1177/1086026608321329

Mygind, N. (2009). „Stakeholder ownership and maximization.“ Corporate Governance, 9, 158-174. http://dx.doi.org/10.1108/14720700910946604

Nelson, J. (2004). „Leadership, accountability, and partnership: Critical trends and issues in corporate social responsibility." Skýrsla á vegum CSR Initiative Launch Event, John F. Kennedy School of Government, Harvard University. http://www.hks.harvard.edu/m-rcbg/CSRI/publications/ report_1_Launch\%20Summary\%20Report.pdf

Nidumolu, R., Prahalad, C.K., \& Rangaswami, M.R. (2009). „Why sustainability is now the key driver of innovation." Harvard Business Review, September 2009, 1-10.

NORD-STAR (2013). „Collaboration with the insurance industry ensures the societal value of research. "Vefsíða. Sótt 15. október 2013 af http://www.nord-star.info/index.php/news/news2/ 84-collaboration-with-the-insurance-industry-ensures-the-societal-value-of-research

OECD (2012). OECD environmental outlook to 2050: The consequences of inaction. OECD Publishing. http://dx.doi.org/10.1787/9789264122246-en

Oppenheim, J., o.fl. (2007). Shaping the new rules of competition: UN Global Compact participant mirror. McKinsey \& Company. Vefslóð: www.unglobalcompact.org/docs/summit2007/ mckinsey_embargoed_until020707.pdf

Porter, M.E., \& Kramer, M.R. (2011). „Creating shared value: How to reinvent capitalism - and unleash a wave of innovation and growth." Harvard Business Review, January-February 2011, 1-17.

Porter, M.E., \& van der Linde, C. (1995). „Green and competitive: Ending the stalemate.“ Harvard Business Review, September-October 1995, 120-134.

Schaltegger, S., \& Burritt, R.L. (2010). „Sustainability accounting for companies: Catchphrase or decision support for business leaders?" Journal of World Business, 45, 375-384. http://dx.doi.org/10.1016/j.jwb.2009.08.002

Schroeder, D. (2002). „Ethics from the top: top management and ethical business.“ Business Ethics: A European Review, 11, 260-267. http://dx.doi.org/10.1111/1467-8608.00284

Smith, A. (1776 / 2005). An inquiry into the nature and causes of the wealth of nations. Electronic Classics Series, Pennsylvania State University.

Smith, A.D. (2007). „Making the case for the competitive advantage of corporate social responsibility.“ Business Strategy Series, 8, 186-195. http://dx.doi.org/10.1108/17515630710684187

Spiller, R. (2000). „Ethical business and investment: A model for business and society.“ Journal of Business Ethics, 27, 149-160. http://dx.doi.org/10.1007/978-94-011-4311-0_15

Sveinn Atli Gunnarsson (e.d.). „Rökleysur loftslagsumræðunnar.“ Vefsíða. Sótt 23. ágúst 2012 af http://www.loftslag.is/?page_id=7451

Taylor, S.J., \& Bogdan, R. (1998). Introduction to qualitative research methods: A guidebook and resource. 3. útgáfa. New York: Wiley.

Thomsen, S. (2001). „Business ethics as corporate governance.“ European Journal of Law and Economics, 11, 153-164. http://dx.doi.org/10.1023/A:1008791702733

Tryggingamiðstöðin (e.d.). „Samfélagsverkefni.“ Vefsíða. Sótt 3. júní 2013 af http://www.tm.is/samfelagsverkefni

Tutore, I. (2010). „Key drivers of corporate green strategy.“ Óbirt ritgerð, Naples Parthenope University/EDAMBA Summer Academy. 
Vátryggingafélag Íslands hf (e.d.). „Umhverfi.“ Vefsỉða. Sótt 3. júní 2013 af http://vis.is/umvis/samfelagsabyrgd/umhverfi

Vísir (2011. 25. nóvember). „Gífurlegt eignatjón eftir ofsaveður í Færeyjum.“ Vefslóð: www.visir.is/gifurlegt-eignatjon-eftir-ofsavedur-i-faereyjum/article/2011111129299

Wilenius, M. (2005). „Towards the age of corporate responsibility? Emerging challenges for the business world." Futures, 37 (2-3), 133-150. http://dx.doi.org/10.1016/j.futures.2004.03.034

Wood, D.J. (1991). „Corporate social performance revisited.“ Academy of Management Review, 16, 691718. http://dx.doi.org/10.2307/258977

World Commission on Environment and Development. (1987). Our common future. Oxford: Oxford University Press.

World Trade Organization (e.d.). „An introduction to trade and environment in the WTO."Vefsíða. Sótt 26. nóvember 2013 af http://www.wto.org/english/tratop_e/envir_e/envt_intro_e.htm.

Yin, R.K. (2009). Case study research: Design and methods. 4. útgáfa. Thousand Oaks: Sage.

Yoder, J., Rao, A., \& Bajowala, M. (2012). PwC Insurance 2020: Turning change into opportunity. PricewaterhouseCoopers International Limited. Vefslóð: www.pwc.com/en_GX/gx/ insurance/pdf/insurance-2020-turning-change-into-opportunity.pdf 